\title{
Malaysia Logistics Higher Education:Past, Present and Future
}

\author{
Mohamed Syazwan Ab Talib ${ }^{1}$, Dazmin Daud ${ }^{2}$ \\ ${ }^{I}$ Faculty of Business and Information Science, UCSI University, Malaysia \\ ${ }^{2}$ Chartered Institute of Logistics and Transport Malaysia, Malaysia
}

\begin{abstract}
Presently, there are 20 public universities, a total of 44 private universities and university colleges, 5 foreign university branch campuses and more than 300 private colleges in Malaysia. In addition, logistics programs in colleges and universities around the world are upward trends and increasing in demand. Lists of all public and private higher learning institutions are obtained from Ministry of Higher Education Malaysia, which then data are collected through series of telephone desktop research, conversations to respective schools, visits to education fairs or open days, and collection of broaches and prospectus. There are 26 higher learning institutions that offer logistics programs which consists of 15 bachelor degree programs, 23 diploma programs and only one professional program. Finally the study managed to introduce a Career Path for Logistics Students and provides several recommendations for logistics higher education in Malaysia.
\end{abstract}

Keywords: Higher Education, Logistics Higher Education, Logistics Career, Malaysia

\section{Logistics Education Background In Malaysia}

The Malaysian government along with higher education institutionshave made countless efforts to increase, improve and promote Malaysia Higher Education system both locally and internationally. Efforts such as Malaysia's National Higher Education Action Plan (2007-2010) and National Higher Education Strategic Plan (NHESP) are some of the efforts to establish Malaysia as an international hub of excellence for higher education, thus in line with the nation's drive towards Vision 2020.

As of 2009, there are 20 public universities, a total of 44 private universities and university colleges, 5 foreign university branch campuses and more than 300 private colleges in Malaysia (Ministry of Higher Education Malaysia, 2010).Furthermore, for the year 2011 alone, a total of 508,256 students studying undergraduate and postgraduate programs in public higher learning institution in Malaysia (Malaysia Higher Education Statistics 2011, 2012). From that encouraging figure, 25,855 students are foreign nationality ranging from Afghanistan to Zimbabwe. Various programs and courses offered by public or private higher leaning institutions in Malaysia are relevant and are highly sought-after, ranging from arts, management, medicine, architecture, engineering and many more.

Among the various programs and courses offered in various public or private higher learning institution in Malaysia, the field of logistics and supply chain is also a popular program and course, both in undergraduate and postgraduate level. According to Lancioni,Forman and Smith (2000), logistics programs in colleges and universities around the world are upward trends and increasing in demand. Logistics and transportation higher education program in Malaysia was establish more than 40 years ago, when InstitutTeknologiMARA (now known as Universiti Teknologi MARA, UiTM) introduced Advance Diploma in Business Administration (Transport) under the Faculty of Business Management and collaboration with the Chartered Institute of Transport (CIT).

Presently, there are 24 higher learning institutions that offers undergraduates program in logistics and transport related fields. There are 22 diplomas, 15 bachelor degrees and one professional degree inlogistics and transport related programs.In addition, there are four higher learning institutions in Malaysia are accredited by the Chartered Institute of Logistics and Transport (CILT) namely Universiti Teknologi MARA (UiTM), Universiti Utara Malaysia (UUM), Universiti Malaysia Terengganu (UMT) and Universiti Kuala Lumpur (UniKL) (CILT Malaysia, 2012). This signifies Malaysia's strength and reputation in providing reputable and high quality logistics and transport related higher education programs.

However, in general, there are still insufficient supplies of qualified logisticians by higher learning institutions (Mangan and Christoper, 2005). According to Dazmin (2009), the Ministry of Higher Education Malaysia must collaborate with the logistics practitioners and professionals to gain the insight and future view of the logistics industry. The views given by the industry professionals are crucial in designing programs and curriculums that are in-line and in demand with the logistics industry requirements. 


\section{Logistics And Higher Education Review}

Logistics is defined as the process of planning, implementing and controlling the efficient, effective flow and storage of goods, service and related information form point of origin to consumption for the purpose of goods, services and related information form point of origin to point of consumption for the purpose of customer requirement (Lambert, Stock and Ellram, 1998).As cited by Rutner and Langley (2000), simple definition of logistics is the fulfillment of the '7Rs of Logistics'; availability of the right product, right quantity, right condition, right place, right time, right customers and right costs. Malaysia is no stranger to logistics industry boasting with magnificent world-class and modern infrastructure as well as renowned logistics companies such as Malaysia International Shipping Corporation (MISC), KontenaNasional (KN), Northport Malaysia Berhad (Northport) and so forth. In the year 2013, the Malaysian logistics industry is expected to increase about $9.5 \%$ to RM139.74 billion (Frost \& Sullivan, 2013). This positive outlook is from the result of constant Government support, the nation's strategic location and the growth of Malaysia external trade from the past years. However, in related news, the lack of professional is logistics industry may hinder and hamper the industry's growth (The Star, 26 January 2011).

Putting logistics into Higher Education context, Erturgut and Soysekerci (2011) feels that the private organizations and public institution are not satisfied with the logistics education provided among the professionals in the industry. It is understood that logistics education is important to professional managers because it increases the employee's efficiency in marketing the goods and services. Furthermore, Erturgut (2011) claimed that not only logistics graduates are able to work in various logistics related fields but also in other disciplines and fields as well.

There are numerous challenges and issues faced by logistics higher education according to Lancioni, Forman and Smith (2001). Among the problems are; lack of trained and qualified faculty members to teach logistics, difficulties in integrating logistics subjects with existing syllabus, the resistance to acknowledge logistics as a respectable area in business and lesser recognition to publish in logistics or supply chain journals. However, presently the demand and recognition for logistics higher education need is growing (Mangan and Lalwani, 2001; Wu, 2007; Dazmin, 2011; Dazmin, 2012).

Therefore, this paper will provide an exploratory analysis of logistics higher education, for undergraduate level, in Malaysia. The aim of this study is to lay down the foundation for future research in logistics higher education in Malaysia as well as to forecast the future direction of logistics higher education and related logistics and higher education researches.

\section{Method And Findings}

In this study, lists of all public and private higher learning institutions, containing the official address, websites, and contacts, are obtained from Ministry of Higher Education Malaysia. From the list, the websites of all the listed institutions are examined in search for any programs that are related with the subject area. Courses offered from all institutions that are related with logistics, supply chain or transport are ignored as some of the institution only offers courses but not a dedicated logistics, supply chain or transport related programs. Besides that, further information are gathered through telephone conversations to respective schools, visits to education fairs or open days, and collection of broachers and prospectus. However, the information gathered are only restricted to undergraduates programs only. Executive programs are also excluded from this study. Once all the date has been collected, a comprehensive list was developed and analysed.

The finding from the research finds several key figures and interesting points to highlight, shown in Table 1. At present, there are 26 higher learning institutions that offer logistics, supply chain or transport related programs and surprisingly, only eight institutions are public owned. Two foreign higher learning institutions (from Singapore and Netherland) established their programs here in Malaysia. Furthermore, a total of 40 programs in related to logistics, supply chain or transport which consists of 15 bachelor degree programs, 23 diploma programs and only one professional program. In addition, only four institutions offer both diploma and degree programs namely Universiti Teknologi MARA (UiTM), Malaysia University of Science and Technology (MUST), Universiti Kuala Lumpur (UniKL) and UCSI University (UCSI).

Table 1: Summary of Logistics Higher Education in Malaysia.

Total of 26 Higher Learning Institutions:

- 8 Public Owned and 18 Private Owned

- 4 Public Universities and 9 Private Universities

Number of Higher

Learning Institutions

- $\quad$ Only 1 University College (Private)

- 4 Polytechnics (Public)

- 3 Public Colleges and 6 Private Colleges

- 2 Institutes (Private) 
Number of Related Undergraduate Programs

Program Accreditation Breakdown
Total of 40 Programs Related to Logistics, Supply Chain or Transport:

- 15 Bachelor Degree Programs

- 23 Diploma Programs

- 1 Professional Qualification (CILT)

Program Accreditation:

- 2 Bachelor Business Administration (BBA)

- 2 Bachelor Business Management (BB)

- 1 Bachelor Management (BM)

- 4 Bachelor Science (BSc)

- 2 Bachelor Arts (BA)

- 1 Bachelor Engineering (BEng)

- 1 Bachelor Information Technology (BIT)

- 1 Bachelor of Entrepreneurship

- 1 Specialized Bachelor (Industrial Logistics)

- 1 Chartered/Professional Qualification

- 23 Diploma Level

In terms of program focus field and specialization i.e. Bachelor Business Administration (BBA) or Bachelor Science (BSc) etc, five programs are in BBA, BB (Bachelor Business) or BM (Bachelor Business Management), four in BSc, two in BA (Bachelor Arts), one Bachelor Engineering (BE) one BM (Bachelor Management), one Business Information Technology (BIT) and one Bachelor Entrepreneurship. Table 2 will provide more details pertaining to logistics, supply chain or transport related undergraduates programs in Malaysia.

Table 2: Logistics, Supply Chain or Transport Related Undergraduates Programs in Malaysia

\begin{tabular}{|c|c|c|c|}
\hline Institute & Ownership & Program & Level \\
\hline $\begin{array}{l}\text { Universiti TeknologiMARA } \\
\text { (UiTM) }\end{array}$ & Public & $\begin{array}{l}\text { Bachelor Business Administration (Hons) Transport } \\
\text { Diploma in Business Studies (Transport) } \\
\text { Charted Institute of Logistics and Transport }\end{array}$ & $\begin{array}{l}\text { Bachelor } \\
\text { Degree } \\
\text { Diploma } \\
\text { Professional }\end{array}$ \\
\hline $\begin{array}{l}\text { Universiti Malaysia Kelantan } \\
\text { (UMK) }\end{array}$ & Public & $\begin{array}{c}\text { Bachelor of Entrepreneurship (Logistics and } \\
\text { Distribution) with Honours }\end{array}$ & $\begin{array}{l}\text { Bachelor } \\
\text { Degree }\end{array}$ \\
\hline $\begin{array}{l}\text { Universiti Malaysia Terengganu } \\
\text { (UMT) }\end{array}$ & Public & $\begin{array}{c}\text { Bachelor of Science (Nautical Science and Marine } \\
\text { Transport) } \\
\text { Bachelor of Management (Maritime) }\end{array}$ & $\begin{array}{l}\text { Bachelor } \\
\text { Degree } \\
\text { Bachelor } \\
\text { Degree }\end{array}$ \\
\hline Universiti Utara Malaysia (UUM) & Public & $\begin{array}{l}\text { Bachelor Business Administration (Logistics and } \\
\text { Transportation) with Honours }\end{array}$ & $\begin{array}{l}\text { Bachelor } \\
\text { Degree }\end{array}$ \\
\hline Politeknik (Poli) & Public & Diploma in Logistics and Supply Chain Management & Diploma \\
\hline $\begin{array}{l}\text { Tunku Abdul Rahman College } \\
\text { (KTAR) }\end{array}$ & Public & $\begin{array}{c}\text { Diploma in Business Studies (Logistics \& Supply } \\
\text { Chain Management) }\end{array}$ & Diploma \\
\hline Kolej Poly-Tech MARA (KPTM) & Public & Diploma in Business Studies (Transport) (UiTM) & Diploma \\
\hline $\begin{array}{c}\text { KolejProfesional MARA Bandar } \\
\text { Penawar (KPM) }\end{array}$ & Public & Diploma in Integrated Logistics Management & Diploma \\
\hline UCSI University (UCSI) & Private & $\begin{array}{c}\text { Bachelor Art (Hons) Logistics Management } \\
\text { Diploma in Logistics Management }\end{array}$ & $\begin{array}{l}\text { Bachelor } \\
\text { Degree } \\
\text { Diploma }\end{array}$ \\
\hline
\end{tabular}




\begin{tabular}{|c|c|c|c|}
\hline \multirow{3}{*}{ Universiti Kuala Lumpur (UniKL) } & \multirow{3}{*}{ Private } & Diploma in Industrial Logistics & Diploma \\
\hline & & Bachelor of Industrial Logistics (Hons) & Bachelor \\
\hline & & $\begin{array}{l}\text { Bachelor of Engineering Technology (Hons) in } \\
\text { Supply Chain Management }\end{array}$ & $\begin{array}{c}\text { Bachelor } \\
\text { Degree }\end{array}$ \\
\hline \multirow{3}{*}{$\begin{array}{l}\text { Malaysia University of Science and } \\
\text { Technology } \\
\text { (MUST) }\end{array}$} & \multirow{3}{*}{ Private } & Diploma in Logistics and Freight Forwarding & Diploma \\
\hline & & Bachelor of Science (Hons) Supply Chain & Bachelor \\
\hline & & $\begin{array}{c}\text { Bachelor of Science (Hons) Transportation and } \\
\text { Logistics }\end{array}$ & $\begin{array}{l}\text { Bachelor } \\
\text { Degree }\end{array}$ \\
\hline $\begin{array}{l}\text { Universiti Tunku Abdul Rahman } \\
\text { (UTAR) }\end{array}$ & Private & $\begin{array}{c}\text { Bachelor of Science (Hons) Logistics and } \\
\text { International Shipping }\end{array}$ & $\begin{array}{c}\text { Bachelor } \\
\text { Degree }\end{array}$ \\
\hline Wawasan Open University (WOU) & Private & $\begin{array}{c}\text { Bachelor of Business (Hons) in Logistics and Supply } \\
\text { Chain Management }\end{array}$ & $\begin{array}{c}\text { Bachelor } \\
\text { Degree }\end{array}$ \\
\hline Universiti Selangor (UNISEL) & Private & $\begin{array}{c}\text { Bachelor of Information Technology with Supply } \\
\text { Chain Management (Hons) }\end{array}$ & $\begin{array}{c}\text { Bachelor } \\
\text { Degree }\end{array}$ \\
\hline $\begin{array}{c}\text { Asia Pacific University of Technology \& } \\
\text { Innovation (APU) }\end{array}$ & Private & $\begin{array}{c}\text { Bachelor Arts (Hons) in Business Management with } \\
\text { specialism in E-Procurement }\end{array}$ & $\begin{array}{c}\text { Bachelor } \\
\text { Degree }\end{array}$ \\
\hline SEGi University (SEGi) & Private & $\begin{array}{c}\text { Bachelor of Business Management (Hons) in Supply } \\
\text { Chain Management }\end{array}$ & $\begin{array}{c}\text { Bachelor } \\
\text { Degree }\end{array}$ \\
\hline Raffels University Iskandar (RUI) & Private & $\begin{array}{c}\text { Bachelor of Business Management (Honours) } \\
\text { (Supply Chain Management) }\end{array}$ & $\begin{array}{c}\text { Bachelor } \\
\text { Degree }\end{array}$ \\
\hline University College Shahputra (UCSA) & Private & Diploma in Logistics Management & Diploma \\
\hline Southern College (SC) & Private & Diploma in Logistics Management & Diploma \\
\hline Han Chiang College (HCC) & Private & Diploma in Logistics Management & Diploma \\
\hline $\begin{array}{c}\text { Bostonweb College of Technology and } \\
\text { Management (BWC) }\end{array}$ & Private & Diploma in Supply Chain Management & Diploma \\
\hline KLIA Professional \& Management & Private & Diploma In Aviation Management & Diploma \\
\hline $\mathrm{Co}$ & & Diploma In Railway Management & Diploma \\
\hline $\begin{array}{c}\text { Cybernetic International College of } \\
\text { Technology (KTAC) }\end{array}$ & Private & Diploma in Aviation Management & Diploma \\
\hline \multirow{4}{*}{ Aviation Management College (AMC) } & \multirow{4}{*}{ Private } & Diploma in Aviation Management & Diploma \\
\hline & & Diploma in Flight Operation Management & Diploma \\
\hline & & Diploma in Aviation Tourism Management & Diploma \\
\hline & & Diploma in Aviation Finance Management & Diploma \\
\hline \multirow{3}{*}{$\begin{array}{l}\text { Netherlands Maritime Institute of } \\
\text { Technology (NMIT) }\end{array}$} & \multirow{3}{*}{ Private } & Diploma in Maritime Transportation Management & Diploma \\
\hline & & Diploma in Port Management & Diploma \\
\hline & & Diploma in Shipping Management & Diploma \\
\hline FMM Institute (FMM) & Private & Diploma in Logistics Management & Diploma \\
\hline
\end{tabular}




\section{Discussion And Recommendation}

In general, logistics management and supply chain management is the mainstream programs in logistics higher education in Malaysia. Notably, there are several programs that are venturing into specialized and dedicated specification in Distribution, Maritime, Aviation, Railway and Procurement. By having a more specialized programs in the logistics field it will optimistically produce more specialized professionals, creating diversity in education line and industrial practice as well as supplying more graduates into the industry that is currently in dire need of well educated talents. Besides that, there are still more efforts needed to be done in order to bring logistics higher education in Malaysia to the same, or better, heights or recognitions with the likes of medicine, architecture, law or engineering fields.

With logistics industry in Malaysia gaining substantial growth coupled with Malaysia's booming higher education sector, the prospects future in logistics industry and logistics higher education is promising and well in line with the nation's Vision 2020. In addition, every students and graduates must be well informed about their career path so that they will have a greater sense and stronger drive to pursue their quest for higher education in the logistics fields. Fig. 1 illustrates the career path for current and potential logistics students and alumni to venture into logistics higher education.

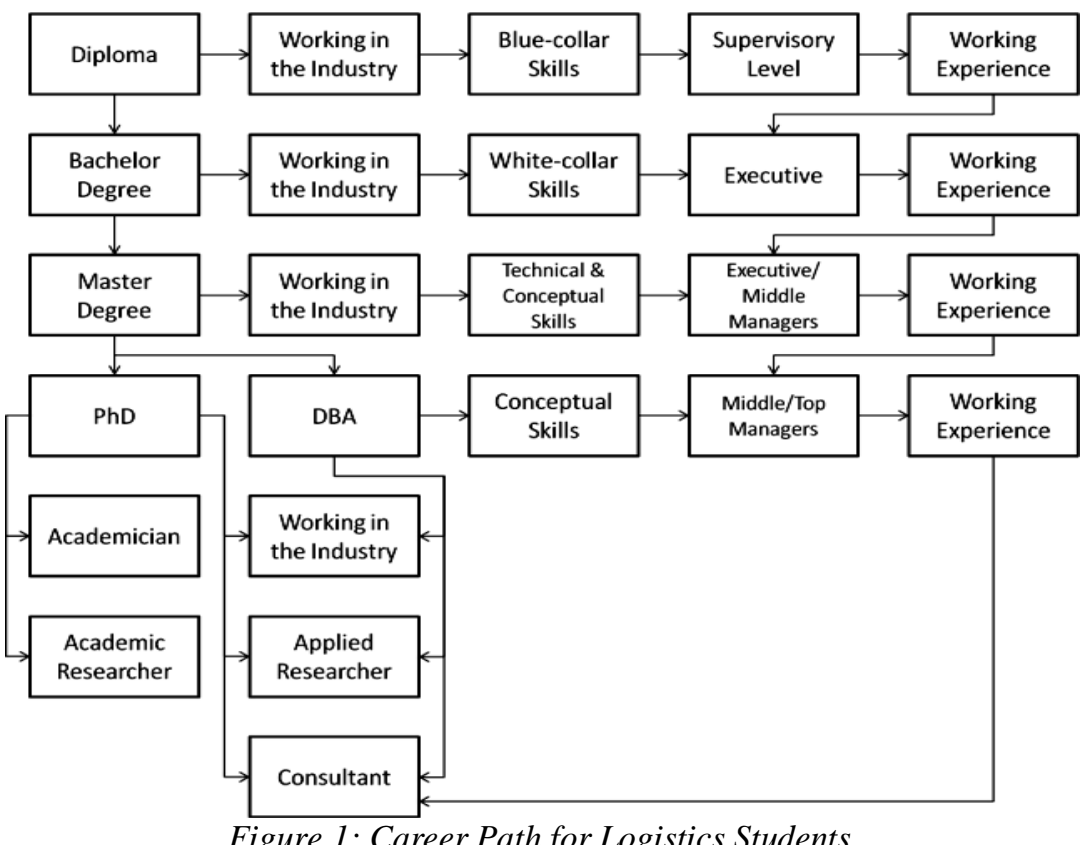

This study provides several recommendations for logistics higher education in Malaysia:

i. More diverse, unique and specialized field of study in logistics and supply chain are needed (warehousing, inventory management, multimodal distribution, logistics information system, purchasing and procurement, reverse or green logistics, etc.)

ii. More intervention and participation from the five Research Universities (UM, UKM, USM, UPM and UTM) are highly encouraged by offering logistics related undergraduate programs orundertaking collaborative partnership.

iii. Twinning programs or dual degree award $(2+1$ or $3+0)$ for logistics related programs from renowned overseas higher learning institutions are highly welcome as currently none existed.

iv. Scholarships opportunity from government or private corporations to logistics students and scholars are needed.

Finally, there are few limitations in this study that needed highlight. Firstly, this study concerns only undergraduates program and neglects the postgraduate programs. Perhaps a more inclusive study involving both undergraduate and postgraduate programs in the future might produce more comprehensive results. Secondly, there are several higher learning institutions that offer executive programs (Postgraduate Diploma, Advance Diploma, Executive MBA, etc.) but this study only take into account all fulltime undergraduate programs. Lastly, this time lapse in conducting this study might result into some programs or information are in time no longer offered or relevant to the study. 


\section{References}

[1] Department of Higher Education, Ministry of Higher Education Malaysia. (2010). List of Public Higher Education Institutions as at December 2009, retrieved from http://jpt.mohe.gov.my/eng/STATISTIK/LISTOFPUBLICANDPRIVATEHIGHE20EDUCTIONIN STITUTIONS.pdf

[2] Ministry of Higher Education Malaysia (2011), Malaysia Higher Education Statistics 2011, retrieved from http://www.mohe.gov.my/web_statistik/perangkaan2011/BAB1-IPTA.pdf

[3] Lancioni, R., Forman, H. \& Smith, M. (2000), Logistics programmes in universities: Stovepipe vs. cross disciplinary, International Journal of Physical Distribution \& Logistics Management,31(1), 53-64.

[4] The Chartered of Logistics and Transport Malaysia (2013), Accredited Professional Degree Program, retrieved from http://www.cilt-m.com.my/en/index.php/about/education/accredited professional-degrees.

[5] Mangan, J. and Christopher, M. (2005), Management development and the supply chain manager of the future, The International Journal of Logistics Management, 16(2), 178-191.

[6] Dazmin, D. (2009), Collaboration for Logistics Education in Malaysia, Bulletin of Higher Education Research,13, 19-21

[7] Lambert, D. M., Stock, J. R. \&Ellram, L. M. (1998), Fundamentals of Logistics Management, Singapore. McGraw-Hill.

[8] Rutner, S. M., \& Langley Jr, C. J. (2000), Logistics value: definition, process and measurement. The International Journal of Logistics Management,11(2), 73-82.

[9] Frost \& Sullivan. (2013). Frost \& Sullivan Sees Bright Prospects for Malaysia's Logistics Industry; Predicts Logistics Revenue to Increase 9.5 per cent year-on-year to RM 139.74 billion in 2013. Frost \& Sullivan. Retrieved from http://www.frost.com/sublib/display-press-release.

[10] Bernama. (2011, January 26), Logistics Sector Projected to Hit RM121 billion This Year. The Star Online. Retrieved fromhttp://biz.thestar.com.my/news/story.asp?file=/2011/1/26/Business $/ 7870387 \&$ sec=business

[11] Erturgut, R., \&Soysekerci, S. (2011), Professional manager education on logistics and supply chain management,Procedia-Social and Behavioral Sciences, 15, 2771-2775.

[12] Erturgut, R. (2011), Increasing demand for logistics technician in business world and rising trend of logistics programs in higher vocational schools: Turkey case,Procedia-Social and Behavioral Sciences, 15, 2776-2780.

[13] Lancioni, R., Forman, H., \& Smith, M. (2001), Logistics and supply chain education: roadblocks and challenges, International Journal of Physical Distribution \& Logistics Management, 31(10), 733-745.

[14] Mangan, J., Gregory, O., \&Lalwani, C. (2001), Education, training and the role of logistics managers in Ireland, International Journal of Logistics, 4(3), 313-327.

[15] Wu, Y. C. J. (2007), Contemporary logistics education: an international perspective, International Journal of Physical Distribution \& Logistics Management, 37(7), 504-528.

[16] Dazmin, D., \& bin Ahmad, H. (2011). A Qualitative Study on Logistics Educational Needs in Malaysian Higher Education Institutions: A Perspective From Logistics Practitioners. International Journal of Human Resource Studies, 1(1), 52-63. 